\title{
THE IMPACT OF INFORMATION - COMMUNICATION TECHNOLOGIES ON DEVELOPMENT OF RURAL TOURISM IN SOUTHERN AND EASTERN SERBIA
}

\author{
Marko Gašić, \\ Goran Perić, \\ Vladan Ivanović
}

Business School of Applied Studies, Blace, Serbia

Correspondence:

Marko Gašić

e-mail:

gasicmarko@yahoo.com

\begin{abstract}
:
Contemporary tourism trends are characterized by the increasing tourist movements towards rural destinations. Tourism in rural areas has become reality, the need and desire of tourists, but also an important activity for development of rural areas. Southern and Eastern Serbia region has great potential for development of rural tourism, but despite this, it is still at an early stage of development. The reason for this situation lies in a number of limiting factors and inadequate valorization of available resources. Therefore, it is necessary to identify the key factors for development and establish the proposed, based on the available resources. One of the limiting factors is the lack of information systems. The subject of this paper is to review the development of rural tourism in the region of Southern and Eastern Serbia, to identify limiting factors and define importance of information - communication technologies in development of rural tourism in the region.
\end{abstract}

Key words:

rural tourism, ICT, development, limiting factors.

\section{INTRODUCTON}

In the middle of the last century, a significant change could be observed in tourism offer and tourism demand. Rural areas, which until now have been rather underdeveloped and uninteresting tourism destinations, have reached the center of attention. On the demand side, there was a need for something new, different ways to spend leisure time and the growing interest in the so-called quality products and different experiences, that is, the tourists want all that mass tourism was no longer able to offer them.

Unfavorable working conditions, monotony, noise and dynamics of urban life are just some of the motives that have contributed to the popularization of rural tourism. Surveys conducted on the territory of Europe indicate that about $20 \%$ of tourists show interest in this form of tourism, with a growing tendency in the future. Free time activities during the weekends and public holidays are increasingly being used to stay in rural areas, whether it is for the purpose of rest. Overall, the rural tourism is increasingly referred to as a global process, which only 40 years ago was additional developed tourism industry.

Over the last few years, Europe has been the leading provider of rural tourism (Gašić, Ivanović, Komadina 2014, p. 38). The movement "back to nature", which has its roots in the fifties of the last century and refers to the fact that "citizens of different social and educational groups want to spend 
part of the holiday in the countryside and experience the rural atmosphere and learn about the rural way of life " (Nikolić 1979, p. 17) is growing.

Organized development of rural tourism in the Republic of Serbia started in the seventies of the twentieth century, in the village of Devići, near Ivanjica (Gašić, Perić, Ivanović 2015, p. 73). In the first years of development, the results were impressive, followed by stagnation in the nineties, which completely annulled the positive results. At the beginning of XXI century, a slight increase could be observed in the rural tourist traffic throughout the country. However, a number of limiting factors, then and now disable the faster development of rural tourism, and one of them is certainly inadequate application of telecommunication information technology and misunderstanding of its importance for rural development and rural tourism.

\section{DEVELOPMENT OF RURAL TOURISM IN THE REGION OF SOUTHERN AND EASTERN SERBIA}

Despite rich in the resource-based, rural tourism in the region of Southern and Eastern Serbia is at an early stage of development. Until recently, the results of the policy in tourism development ignored the inclusion of the continental part of our country in the tourist offer. As a result, over $90 \%$ of the total number of overnight stays was registered in the coastal areas (Štetić 2007, p. 233). On the other hand, very significant natural and human resources in the continental part of the Republic were under-used, or not used at all, as was the case with the region of Southern and Eastern Serbia. This field of rural tourism, whose significance has not been sufficiently explored beside all of it possibilities and basides on the experience of many European countries, is virtually limitless in future development.

With the changes that occurred in the second half of the twentieth century at the global level, particularly in the late nineties, rural tourism has become an increasingly important trend. General booming tourist movement in general, and especially to the rural areas from urban centers points to the growing importance of these movements, which if exploited in the right way can bring numerous benefits, both at the community level and at the state level.

Thanks to mainly hilly and mountainous nature of the region, there is a large number of rural areas with favorable conditions for rural tourism development. However, there is a small number of villages which managed to provide these services. Some of them are shown in the following table.

\begin{tabular}{|c|c|}
\hline District & $\begin{array}{l}\text { Villages in which has } \\
\text { developed rural tourism }\end{array}$ \\
\hline Podunavlje & $\begin{array}{l}\text { Jugovo, Aleksandrovac, Moravski } \\
\text { konaci }\end{array}$ \\
\hline Braničevo & $\begin{array}{l}\text { Aljudovo, Salakovac, Kaona, Ždrelo, } \\
\text { Malo Laole }\end{array}$ \\
\hline Bor & $\begin{array}{l}\text { Gornjane, Metovnica, Zlot, Džanovo } \\
\text { polje, Šarbanovac, Luka, Bučje, } \\
\text { Crnojka, Rudna Glava, Rajac, } \\
\text { Rogljevo, Plavna }\end{array}$ \\
\hline Zaječar & $\begin{array}{l}\text { Crni Vrh, Balta Berilovac, Kalna, } \\
\text { Vrtovac, Inovo, Jakovac, Jakovac, } \\
\text { Mezdreja, Mali Izvor, Ilino, Rgošte, } \\
\text { Ravna, Potrkanje, Gradište, Lužinac, } \\
\text { Vrmdža, Trubarevac, Jošanica, } \\
\text { Žuškovac }\end{array}$ \\
\hline Nišava & $\begin{array}{l}\text { Pirkovac, Niševac, Beloinje, Dubrava, } \\
\text { Donji Dušnik, Semče, Gornej Vlase, } \\
\text { Gornji Barbeš }\end{array}$ \\
\hline Jablanica & $\begin{array}{l}\text { Dadince, Magaš, Ivanje, Dobra Voda, } \\
\text { Gornji Brestovac, Borince, Sijarinska } \\
\text { spa }\end{array}$ \\
\hline Pirot & $\begin{array}{l}\text { Dojkinci, Rsovci, Jelovica, Slavinja, } \\
\text { Brlog, Osmakovo, Vojnegovac, Topli } \\
\text { Do, Gradašnica, Visočka Ržana, } \\
\text { Temska, Kamenica, Poganovo, Donji } \\
\text { Krivodol, Senokos }\end{array}$ \\
\hline Toplica & $\begin{array}{l}\text { Bublica, Togačevče, Cekavica, } \\
\text { Prekopčelica, Štulac, Svinjarica, Beli } \\
\text { kamen, Lukovska spa, Prolom spa, } \\
\text { Kastrat }\end{array}$ \\
\hline Pčinja & $\begin{array}{l}\text { Poljanica, Kriva Feja, Duga Luka, } \\
\text { Zagužanje, Jablanica }\end{array}$ \\
\hline
\end{tabular}

Table 1. Villages in the region of Southern and Eastern Serbia with developed rural tourism Source: own research

Data on accommodation in rural tourism in households in the region of Southern and Eastern Serbia have not been covered by the official statistics. Available resources include portal Rural Tourism (www.selo.rs) and local tourism organizations (Bogdanov, Zečevic, 2011, p. 37). Types of properties in rural tourism, according to the data from Rural Tourism Association of Serbia, and relations to the region of Southern and Eastern Serbia, are shown in the following table. 


\begin{tabular}{|c|c|c|c|c|}
\hline $\begin{array}{l}\text { Municipal- } \\
\text { ity }\end{array}$ & $\begin{array}{l}\text { Number of } \\
\text { accom- } \\
\text { modation } \\
\text { facilities }\end{array}$ & $\begin{array}{l}\text { Type of } \\
\text { accomo- } \\
\text { dation }\end{array}$ & $\begin{array}{l}\text { Number } \\
\text { of beds }\end{array}$ & Activities \\
\hline Žagubica & 1 & $\begin{array}{l}\text { Ethno } \\
\text { village }\end{array}$ & 18 & $\begin{array}{l}\text { Traditional food, visit- } \\
\text { ing cultural - historical } \\
\text { monuments }\end{array}$ \\
\hline Bor & 1 & Beds & 6 & $\begin{array}{l}\text { Cycling, recreation, } \\
\text { fishing, walking, hiking, } \\
\text { swimming }\end{array}$ \\
\hline Knjaževac & 1 & $\begin{array}{l}\text { Rural } \\
\text { house- } \\
\text { hold }\end{array}$ & 10 & $\begin{array}{l}\text { Resting in the nature, } \\
\text { hiking, fishing, biking, } \\
\text { hunting }\end{array}$ \\
\hline $\begin{array}{l}\text { Dimitro- } \\
\text { vgrad }\end{array}$ & 1 & $\begin{array}{l}\text { Rural } \\
\text { house- } \\
\text { hold }\end{array}$ & 8 & $\begin{array}{l}\text { Ride bikes, walk in na- } \\
\text { ture, traditional food }\end{array}$ \\
\hline \multirow[t]{2}{*}{$\begin{array}{c}\text { Bela } \\
\text { Palanka }\end{array}$} & 1 & $\begin{array}{l}\text { Guest } \\
\text { house }\end{array}$ & - & $\begin{array}{l}\text { Hiking, swimming, } \\
\text { visiting religious sites }\end{array}$ \\
\hline & 1 & $\begin{array}{l}\text { Apart- } \\
\text { ments }\end{array}$ & 20 & $\begin{array}{l}\text { Hiking, swimming, } \\
\text { walking, cycling }\end{array}$ \\
\hline \multirow[t]{2}{*}{ Sokobanja } & 1 & Beds & 4 & $\begin{array}{l}\text { Swimming, outdoor ac- } \\
\text { tivities, visiting cultural } \\
\text { - historical monuments }\end{array}$ \\
\hline & 1 & $\begin{array}{l}\text { Rural } \\
\text { house- } \\
\text { hold }\end{array}$ & 5 & $\begin{array}{l}\text { Hiking, bathing in } \\
\text { thermal waters, hiking, } \\
\text { biking, visiting historic } \\
\text { buildings }\end{array}$ \\
\hline Pirot & 1 & $\begin{array}{l}\text { Guest } \\
\text { house }\end{array}$ & 6 & $\begin{array}{l}\text { Skiing, picking herbs, } \\
\text { hiking, walking, biking, } \\
\text { mushroom collecting }\end{array}$ \\
\hline
\end{tabular}

Table 2. Accommodation capacity of rural tourism in the region

Source: selo.rs

Based on the Table 2, it is possible to conclude that rural tourism is developed in a few villages in the region. However, due to insufficient application of modern information and communication technologies as well as inadequate level of education of the owners of rural tourist households, many of them have presented an offer within the site. Households engaged in rural tourism are far greater but are not engaged in this activity at all,and without organization or network about them, there are no precise data.

On the other hand, organized statistical monitoring in this segment of tourism is still at initial phase, but it can still be a reference. A large number of states, including the Republic of Serbia, do not collect statistics linked with rural tourism observations, especially in relation to other forms of tourism. However, the current development of rural tourism in the Republic of Serbia can be analyzed on the basis of data published by the Republic Statistical Office and related to tourist traffic viewed from the aspect of the realized number of overnights (Radović 2013, p.
120). The average percentage of overnight stays in rural tourism is $21 \%$ of the total number of overnight stays at the global level as well as at the country level (see Table. 3).

\begin{tabular}{ccc}
\hline Year & $\begin{array}{c}\text { Realized number of over- } \\
\text { night stays in all tourist } \\
\text { areas of the region }\end{array}$ & $\begin{array}{c}\text { Realized number of over- } \\
\text { night stays in rural areas of } \\
\text { the region }\end{array}$ \\
\hline 2004 & 1447790 & 304036 \\
\hline 2005 & 1379610 & 289718 \\
\hline 2006 & 1302608 & 273548 \\
\hline 2007 & 1472707 & 309268 \\
\hline 2008 & 1541735 & 323764 \\
\hline 2009 & 1346368 & 282737 \\
\hline 2010 & 1314707 & 276088 \\
\hline 2011 & 1350476 & 283600 \\
\hline 2012 & 1315434 & 276241 \\
\hline 2013 & 1106177 & 232297 \\
\hline 2014 & 995948 & 209149 \\
\hline
\end{tabular}

Table 3. Tourist traffic - the number of realized overnight stays in rural tourism in the region (2004-2014)

Source: Calculation based on the data of the Statistical Office of the Republic of Serbia

Given that the World Tourism Organization as well as the Organization for Economic Co-operation and Development failed to take appropriate measures, there are several constraints involved when it comes to providing accurate and logical data in connection with rural tourism and recreation (Petrić 2006, p. 7): First, the area where rural tourism is developing is difficult to define because different countries take into account different criteria; Secondly, all tourist activities in rural areas do not have to be strictly rural, but in its content can be urban, or only take place in rural areas; Thirdly, different regions develop different forms of rural tourism, and is therefore difficult to find common characteristics for all countries; Fourthly, rural areas have engulfed the complex change processes arising as a result of changes in the global market, particularly in the area of contemporary information and communication technologies, which are changing market conditions and demand for traditional products.

\section{LIMITING FACTORS IN DEVELOPMENT OF RURAL TOURISM IN SOUTHERN AND EASTERN SERBIA}

Previous efforts to develop rural tourism were not satisfactory. Resources for the development of rural tourism in the region of Southern and Eastern Serbia are related primarily to the fact that over $90 \%$ of the territory of the 
region consists of rural areas, express geographically diversified in the form of hilly - mountainous areas. Around $70 \%$ of the total population lives in rural areas and multiethnic structure of the population which, which clearly indicates unexplored potential.

Unsatisfactory level of development of rural tourism in the region is the result of a number of limiting factors. Some of them are: unfavorable demographic trends, the lack of financial resources, inadequate rural infrastructure, lack of cooperation between different levels of government, lack of interest and motivation of the rural population to engage in this form of tourism, insufficient education and others. The lack of application of modern information and communication technologies is one of the factors that can also affect the development of rural tourism and that can also be seen as a limiting factor.

The causes of this problem must be found in, above all, the indicator of computer literacy. On the basis of that, it is possible to give appropriate recommendations for the next period. See Table 4.

\begin{tabular}{|c|c|c|c|}
\hline \multirow{4}{*}{ Categories } & & $\begin{array}{l}\text { Republic of } \\
\text { Serbia }\end{array}$ & $\begin{array}{c}\text { Southern } \\
\text { and Eastern } \\
\text { Serbia } \\
\text { Region }\end{array}$ \\
\hline & total & 6161584 & 1347323 \\
\hline & man & 2971868 & 661251 \\
\hline & woman & 3189716 & 686072 \\
\hline \multirow{3}{*}{$\begin{array}{l}\text { Computer literate } \\
\text { persons }\end{array}$} & total & 2108144 & 362832 \\
\hline & man & 1062125 & 191272 \\
\hline & woman & 1046019 & 171560 \\
\hline \multirow{3}{*}{$\begin{array}{l}\text { Persons who are } \\
\text { partially familiar } \\
\text { with the work on the } \\
\text { computer }\end{array}$} & total & 910586 & 193506 \\
\hline & man & 463780 & 101374 \\
\hline & woman & 446806 & 92132 \\
\hline \multirow{3}{*}{$\begin{array}{c}\text { Computer illiterate } \\
\text { persons }\end{array}$} & total & 3142854 & 790985 \\
\hline & man & 1445963 & 368605 \\
\hline & woman & 1696891 & 422380 \\
\hline
\end{tabular}

Table 4. Computer literacy in the region

Source: Statistical Office of the Republic of Serbia

According to this indicator, Serbia is below the EU average, but more computer-literate than some of its members, such as Romania and Bulgaria. At the regional level, the indicator is below the national average while the biggest problem of computer literacy is expressed in Jablanica and Zaječar district.
If we analyze the entire structure, it is possible to observe significantly greater participation of women in the group of computer-illiterate persons or group of persons partially familiar with the work on the computer. The causes of this phenomenon should be found in the position of women in the countryside and centuries of domination of the male population in most jobs. Nevertheless, this situation is gradually improving if we perceive the figures of male and female participation in previous census years.

Overall, regardless of the fact that the situation in the field of application of modern information and communication technology in rural tourism is gradually improving, it is still viewed as unsatisfactory. It is evident that the possibilities offered by modern technology are not sufficiently explored in rural areas in the Southern and Eastern part of Serbia, and that this still does not meet the appropriate conditions.

\section{IMPORTANCE OF INFORMATION AND COMMUNICATION TECHNOLOGIES IN DEVELOPMENT OF RURAL TOURISM}

In order to achieve successful development of rural tourism in the region, it is necessary to dispose not only of attractive natural and human resources, capacity and quality products, but also efficient organization, adequate education and well-designed marketing. Owing to the changing lifestyles, economic conditions and other characteristics of tourists, tourist market is shifting from not so critical mood conventional tourists who were easily manipulated to mature, critical and emancipated, socalled new tourists. New needs, new interests and new knowledge about the destination of rural tourists carry with them; require a different approach to marketing in rural tourism, as it was the case with other forms of tourism (Stojanović 2011, pp. 194-195).

The approach of planning for tourism development in rural areas of the region, with particular importance at market research and the use of marketing instruments, must include the Internet because of its advantages over other instruments. Numerous studies have confirmed that the Internet as a global network with its various services is increasingly used in the promotion of all forms of tourism, including rural tourism. Thus, the population located in rural areas of the region has the opportunity to access the Internet and social networks and create their own content and publish it worldwide in order to attract potential tourists. 
The importance of information technology and the Internet is evident and is of strategic importance in the development of rural areas. New information technologies offer unprecedented possibilities for initiatives in rural tourism, allow visitors quick and easy access to information, the ability to offer online reservations and other activities that are related to their departure to your destination. The importance of the Internet promotion is that in this way information is made widely available to potential users, who can more easily plan the journey (Todorović, Štetić 2009, p. 109).

Social networks encourage development of rural and less developed regions networks, households, local governments, tourist organizations and businesses that are directly or indirectly reliant on tourism. A number of social networks can be used in development of rural tourism and to achieve competitive advantages in both domestic and international markets. Social networks such as Facebook, Twitter, YouTube and Google Maps can be of great importance in tourism planning (Zrilić 2012, p. 346).

The importance and role of the Internet in general and contemporary technology in the development of rural tourism is priceless. The survey conducted by the Internet Advertising Bureau, with respect to the effectiveness of the promotion on the Internet, revealed the following results: (Čomić, Kosar, 2011, p. 27):

- The level of acceptance of the Internet as a means of advertising is much higher compared to traditional media

- Advertising on the Internet dramatically increases the awareness of the product after just one viewing site

- Advertising on the Internet significantly increases the awareness of the brand or product promoted

- Significant increase in communication power of a particular brand if it is promoted via the Internet

- Advertising on the Internet has the potential to increase sales

- Advertising on the Internet is more likely to be noticed than advertising on television

- Internet and other electronic information technology can influence the search of tourist information as well as the travel decision-making and choice of destinations.

Based on the above-stated, modern ICT, the Internet and social networks can be characterized as a necessity in modern business.

\section{CONCLUSION}

Changes that occur globally positively affect the development of selective forms of tourism, as tourism is based on the use of different natural and social resources. Attention must be paid to certain segments of the system, especially the development of tourism in rural areas.

Rural tourism has been expanding in recent years; due to the growing needs of urban population for recreation in a different area, under rural setting. In addition, rural demand for peace, rest and recreation is a growing trend at the regional, national, European and international level. In Serbia, this form of tourism is still at its initial stage.

Southern and Eastern Serbia owns attractive natural and cultural tourist motifs that have not yet been adequately socio - economic valorized. The reasons should be sought in a number of limiting factors, among which certainly should be highlighted the lack of knowledge and application of modern information and communication technologies and the benefits they provide, especially in the promotion of tourist offer of rural households.

Importance of information technology and the Internet are evident, and thus strategically important in development of rural tourism. One of the priority tasks at the regional level will be organizing a number of training courses on which the owners of rural tourist households are informed to the benefits of modern technology and the importance of promotion of their offers on the Internet. The Internet is the best and fastest way (channel) for transmitting and exchanging information.

\section{REFERENCES}

Bogdanov, N., Zečević, B. (2011). Javno - privatno partnerstvo u razvoju ruralnog turizma. Program Ujedinjenih nacija za razvoj (UNDP) u okviru zajedničkog programa Ujedinjenih nacija „Održivi turizam u funkciji ruralnog razvoja", Beograd.

Čomić, Đ., Kosar, Lj. (2001). Globalne komunikacije i turizam. Turizam. br. 5, str. 27-28.

Gašić, M., Ivanović, V., Komadina, M. (2014). Razvoj ruralnog turizma u Evropskoj uniji. BizInfo (Blace). 5(2), str. 33-44. DOI:10.5937/BIZINFO1402033G

Gašić, M., Perić, G., Ivanović, V. (2015). Razvijenost ruralnog turizma u Republici Srbiji. BizInfo (Blace). 6(2), str. 71-83. DOI:10.5937/BIZINFO1502071G

Nacionalna asocijacija Seoski turizam Srbije. (2002). Accommodation type. 30.03.2016, http://www.selo.rs/EN

Petrić, L. (2006). Izazovi razvoja ruralnog turizma: dosadašnja praksa u Europi i reperkusije na Hrvatsku. 
Acta Turistica. 18.(2), pp. 138-170.

Radović, G. (2013) Problemi razvoja ruralnog turizma u Republici Srbiji. Agroekonomika. Br. 59-60/2013, str. 114-123.

Statistical Office of the Republic of Serbia. (2004-2015). Statistical Yearbook of the Republic of Serbia, Belgrade.

Štetić, S. (2007). Turistička geografija Srbije, Beograd

Stojanović, V. (2011). Turizam i održivi razvoj. Novi Sad: PMF.
Todorović, M., Štetić, S. (2008). Ruralni turizam. Beograd: Geografski fakultet.

Zrilić, D. (2012). Značaj informaciono komunikacionih tehnologija za održivi razvoj turizma u ruralnim, perifernim i manje razvijenim regionima. U: Sedmi naučni skup sa međunarodnim učešćem „Turizam - izazovi i mogućnosti”. Trebinje, 20 - 22. Septembar 2012. Beograd: Ekonomski institut. 